\title{
Perilaku Satwa Liar Pada Kelas Mammalia
}

\author{
Inka Alfila ${ }^{1}$, Muhammad Radhi ${ }^{1}$ \\ ${ }^{1}$ Mahasiswa Program Studi Kehutanan. Fakultas Pertanian, Universitas Almuslim, Jalan Almuslim, Matang \\ Glumpang Dua, Peusangan, Kabupaten Bireuen, Aceh 24261 \\ Email: inkaalfila98@gmail.com
}

\begin{abstract}
ABSTRAK
Perilaku satwa liar merupakan gerak gerik satwa liar untuk memenuhi rangsangan dalam tubuhnya dengan memanfaatkan rangsangan yang diperoleh dari lingkungannya. Mamalia adalah hewan atau binatang bertulang belakang (vertebrata) yang berdarah panas, dapat dibedakan dengan memiliki rambut, dan sistem reproduksinya dengan cara melahirkan dan menyusui anaknya. Tujuan pengamatan jurnal ini adalah untuk mengetahu perilaku seksual, perilaku sosial, perilaku makan, perilaku khas, dan perilaku pergerakan maupun aktivitas harian golongan mamalia diantaranya Orangutan sumatera(Pongo abelii), Trenggiling (Manis javanica), Gajah sumatera (Elephas maximus sumatranus), Beruk (Macaca namestrina), Tapir Asia (Tapirus indicus) dan mengetahui status konservasi masing-masing mamalia berdasarkan IUCN (International Union For Conservation Of Nature)
\end{abstract}

Kata kunci: perilaku harian, mamalia, IUCN

\section{PENDAhUluan}

Setiap makhluk hidup akan melakukan interaksi dengan lingkungannya sejak pertama kali dilahirkan. Untuk tetap eksis setiap makhluk hidup harus mampu melakukan adaptasi, baik pada tingkatan populasi maupun komunitas pada suatu biosfer. Kajian perilaku hewan pada dasarnya mempelajari bagaimana hewan-hewan berperilaku di lingkungannya dan setelah para ahli melakukan interpretasi, diketahui bahwa perilaku merupakan hasil dari suatu penyebab atau suatu "proximate cause" (Fachrul, 2007). Satwa liar adalah semua binatang yang hidup di darat, air, dan di udara yang masih mempunyai sifat-sifat liar, baik yang hidup bebas maupun yang dipelihara oleh manusia, satwa liar dapat juga diartikan binatang yang hidup liar di alam bebas tanpa campur tangan manusia (Alikodra, 1990). Perilaku merupakan kebiasaan-kebiasaan satwa liar dalam aktifitas hariannya seperti sifat kelompok, waktu aktif, wilayah pergerakan, cara mencari makan, cara membuat sarang, hubungan sosial, tingkah laku bersuara, interaksi dengan spesies lainnya, cara kawin dan melahirkan anak. Perilaku satwa liar merupakan gerak gerik satwa liar untuk memenuhi rangsangan dalam tubuhnya dengan memanfaatkan rangsangan yang diperoleh dari lingkungannya. Perilaku juga di pelajari didalam penangkaran untuk dapat mngamati secara langsung. Penangkaran adalah upaya untuk menjaga populasi yang terancam punah (Akmal et al., 2015)

Mamalia adalah hewan atau binatang bertulang belakang (vertebrata) yang berdarah panas, dapat dibedakan dengan memiliki rambut, dan sistem reproduksinya dengan melahirkan anaknya. Kelompok ini merupakan hewan yang menyusui anaknya, dan memiliki ciri-ciri lainnya yang membedakan dengan kelompok hewan lainnya. Mamalia memiliki susunan gigi yang bervariasi, artinya sudah dibedakan dengan adanya gigi seri (incisors), gigi taring (canine), dan gigi geraham (molar), terkecuali pada sebagian besar mamalia laut yang bergigi seragam (satu bentuk) dan trenggiling (Manis javanica) yang tidak mempunyai gigi. Tulang rahang bawah (mandible) mamalia tersusun oleh tulang tunggal, dan butir darah merah tidak memiliki inti. Populasi mamalia yang termasuk satwa liar memiliki potensi penurunan populasi akibat kehilangan habitat, perburuan, perdagangan liar oleh tingginya harga dan permintaan pasar (Akmal et al., 2019)

Namun, sedikit orang yang tahu dan paham tentang keanekaragaman jenis mamalia liar yang sangat luar biasa, khususnya di Indonesia. Di dunia, lebih dari 4.400 spesies diketahui dari seluruh dunia, dan lebih dari 500 spesies diantaranya dicatat dari kawasan Asia Tenggara seperti banteng (Bos javanicus), gajah (Elephas spp.), badak (Rhinoceros 
spp.), babi hutan (Sus spp.), kucing hutan (Felis spp.), beruang (Helarctos malayanus), kera/monyet (Macaca spp.), kelelawar (Cynopterus spp.), dan jenis-jenis lain dengan ukuran yang lebih kecil seperti rodensia (Rattus spp.) dan cecurut (Crocidura spp.).

Di Indonesia, sampai dengan tahun 2019, jenis mamalia yang tercatat kurang lebih 776 jenis dan terbagi menjadi 16 bangsa atau ordo, termasuk beberapa jenis baru yang ditemukan dalam kurun waktu 10 tahun terakhir (2010- 2019) diantaranya Paucidentomys vermidax (2012), Margaretamys cristinae (2012), Halmaheramys bokimekot (2013), Waiomys mamasae (2014), Hyorhinomys stuempkei (2015), Crocidura umbra (2016), Gracilimus radix (2016), Tarsius spectrumgurskyae dan Tarsius supriatnai (2017). Sedangkan terkait distribusinya, komposisi sebaran mamalia terbesar terdapat di Pulau Kalimantan (268 jenis), diikuti Sumatera (257 jenis), Papua (241 jenis) dan Sulawesi (207 jenis), dan Pulau Jawa diurutan kelima dengan 193 jenis. Saat ini satwa liar memiliki nilai ekonomis yang tinggi sehingga terjadinya perburuan liar semakin meningkat, sehingga dugaan populasi satwa liar berkurang secara dramatis dari tahun ke tahun (Akmal et al., 2014a).

Ilmu yang mempelajari perilaku satwa disebut sebagai etologi. Etologi adalah studi ilmiah dan objektif tentang perilaku hewan, biasanya dengan fokus pada perilaku dalam kondisi alam, dan melihat perilaku sebagai sifat adaptif evolusioner. Etolog biasanya tertarik pada proses perilaku pada kelompok satwa tertentu, dan sering mempelajari satu jenis perilaku, seperti agresi, makan, sexual dan sosial. Informasi tentang status biologi reproduksi satwa liar sangat penting untuk pelaksanaan kegiatan konservasi ex situ. Salah satu aspek dalam biologi reproduksi satwa liar adalah pengetahuan tentang anatomi dan siologi organ reproduksi baik jantan maupun betina (Akmal et al., 2014b). Perilaku seksual adalah segala perilaku yang muncul karena adanya dorongan kegiatan mendapatkan kesenangan organ sexual melalui berbagai perilaku dengan cara merangsang.

Perilaku Sosial adalah Perilaku yang dilakukan oleh satu individu atau lebih yang menyebabkan terjadinya interaksi antar individu dan antar kelompok. Perilaku ini bisa dibagi menjadi : a. Perilaku Affiliative : adalah perilaku yang dilakukan bertujuan untuk mempererat ikatan social, koordinasi antar individu dan kebersamaan antar atau di dalam kelompok.

b. Perilaku Agonistic :

- Perilaku aggressive: Perilaku yang bersifat mengancam atau menyerang.

- Perilaku submissive: Perilaku yang menunjukkan ketakutan atau kalah.

c. Vokalisasi Adalah suara yang dikeluarkan oleh satu atau lebih individu untuk berkomunikasi dan koordinasi diantara anggota kelompoknya

d. Perilaku maternal/mothering adalah Perilaku induk yang bertujuan melindungi dan memelihara anaknya

Perilaku makan, setiap makhluk hidup memerlukan makan untuk dapat bertahan hidup. Perilaku makan adalah cara-cara individu dan kelompok individu memilih, mengkonsumsi, dan menggunakan makanan-makanan yang tersedia, yang didasarkan kepada faktor-faktor sosial dimana individu tersebut hidup. Perilaku khas adalah perilaku unik yang hanya dimiliki oleh individu tertentu, yang tidak dimiliki oleh individu lainnya.

Perilaku pergerakan dilakukan untuk mencari makan, berkembang biak, ataupun menghidarkan diri dari predator dan gangguan lainnya. Ada dua hal yang menentukan perilaku pergerakan satwa liar yaitu faktor primer dan sekunder. Faktor-faktor primer yang mendorong satwa untuk bergerak agar kebutuhan fisiologinya terpenuhi, seperti rasa lapar, haus, dan motivasi seksual. Oleh karna itu distribusi pakan,air dan perkawinan diduga menjadi penentu utama dari penggunaan suatu tempat. Fungsi sekunder sendiri adalah faktor-faktor yang memodifikasi penggunaan ruang dapat mencakup sekurang-kurangnya variasi mikro-klimat suatu temmpat, keadaan medan, resiko bertemu predator atau jenis yang sama dan resiko terkena penyakit. Tujuan pengamatan jurnal ini adalah untuk mengetahu perilaku seksual, perilaku sosial, perilaku makan, perilaku khas, dan perilaku pergerakan maupun aktivitas harian golongan mamalia. 


\section{PEMBAHASAN}

\section{Orangutan Sumatera}

Orangutan sumatera atau Pongo abelii merupakan satu diantara 11 hewan mamalia paling langka di Indonesia. dan merupakan spesies primata besar paling langka di dunia. orangutan sumatera memiliki postur tubuh yang besar, lengan yang panjang dan kuat, kaki pendek, dan tidak memiliki ekor. Pada tubuhnya ditumbuhi bulu (rambut) berwarna merah kecoklatan. Jantan dewasa memiliki ukuran tubuh dua kali lebih besar dibandingkan betinanya, yaitu berkisar antara $125-150 \mathrm{~m}$. Berat tubuh jantan berkisar antara $50-90 \mathrm{~kg}$, sedangkan betina berkisar antara $30-50 \mathrm{~kg}$. Tubuh berukuran besar dan berwarna kayu manis. Betina mempunyai jenggot dan jantan berjenggot besar, moncong kurang prognathous dan dari depan berbentuk menyerupai huruf O. Pipi jantan rata dan tertutup dengan rambut yang halus, tengkorak tidak memiliki lekuk antar tulang mata.

Sebagai hewan endemik sumatera, Orangutan sumatera hanya bisa dijumpai di pulau Sumatera. Beberapa kawasan yang menjadi habitat primata besar ini antara lain di Sumatera bagian utara (Aceh dan Sumatera Utara) seperti di Taman Nasional Gunung Leuser dan Suaka Margasatwa Bukit Lawang. Beberapa tahun terakhir telah dilakukan reintroduksi orangutan sumatera ke kawasan Taman Nasional Bukit Tiga Puluh (Jambi dan Riau).

Populasi orangutan sumatera (Pongo abelii) semakin hari semakin menurun. Dalam status konservasi yang dikeluarkan oleh IUCN Redlist, status orangutan sumatera adalah Kritis (Critically Endangered). Kategori ini diperuntukkan untuk jenis yang dinyatakan memenuhi kriteria menuju kepunahan dan tengah menghadapi risiko tinggi kepunahan di alam liar dengan tingkat yang lebih ekstrim.

\section{a. Perilaku Makan}

orangutan termasuk hewan omnivora, sebagian besar dari mereka hanya memakan tumbuhan $90 \%$ dari makanannya berupa buahbuahan. Makanannya antara lain adalah kulit pohon, dedaunan, bunga, beberapa jenis serangga, dan sekitar 300 jenis buah-buahan. Selain itu mereka juga memakan nektar, madu dan jamur. Mereka juga gemar makan durian, walaupun aromanya tajam, tetapi mereka menyukainya. Orang utan bahkan tidak perlu meninggalkan pohon mereka jika ingin minum. Mereka biasanya meminum air yang telah terkumpul di lubang-lubang di antara cabang pohon. Biasanya induk orang utan mengajarkan bagaimana cara mendapatkan makanan, bagaimana cara mendapatkan minuman, dan berbagai jenis pohon pada musim yang berbeda-beda pada anaknya. Melalui ini, dapat terlihat bahwa orang utan ternyata memiliki peta lokasi hutan yang kompleks di otak mereka, sehingga mereka tidak menyia-nyiakan tenaga pada saat mencari makanan. Anaknya juga dapat mengetahui beragam jenis pohon dan tanaman, yang mana yang bisa dimakan dan bagaimana cara memproses makanan yang terlindungi oleh cangkang dan duri yang tajam.

\section{b. Perilaku Seksual}

Orang utan betina biasanya melahirkan pada usia 7-10 tahun dengan lama kandungan berkisar antara 8,5 hingga 9 bulan; hampir sama dengan manusia. Jumlah bayi yang dilahirkan seorang betina biasanya hanya satu. Bayi orang utan dapat hidup mandiri pada usia 6-7 tahun. Ketergantungan anak orang utan pada induknya merupakan yang terlama dari semua hewan, karena ada banyak hal yang harus dipelajari untuk bisa bertahan hidup, mereka biasanya dipelihara hingga berusia 6 tahun. Orangutan berkembangbiak lebih lama dibandingkan hewan primata lainnya, orangutan betina hanya melahirkan seekor anak setiap 7-8 tahun sekali. Umur orangutan di alam liar sekitar 45 tahun, dan sepanjang hidupnya orang utan betina hanya memiliki 3 keturunan seumur hidupnya yang berarti reproduksi orang utan sangat lambat.

\section{c. Perilaku Sosial}

Tidak seperti gorila dan simpanse, orangutan tidak hidup dalam sekawanan yang besar. Mereka merupakan hewan yang semi-soliter. Orangutan jantan biasanya ditemukan sendirian dan orangutan betina biasanya ditemani oleh beberapa anaknya. Orangutan adalah hewan arboreal, artinya ia hidup atau beraktivitas di atas pohon. Hal ini berbeda dengan kera besar lainnya, seperti gorilla dan simpanse, yang merupakan hewan terrestrial (menghabiskan hidup di tanah).

\section{d. Perilaku Pergerakan}

Orang utan dapat bergerak cepat dari pohon kepohon dengan cara berayun pada cabang-cabang 
pohon, atau yang biasa dipanggil brachiating. Mereka juga dapat berjalan dengan kedua kakinya, namun jarang sekali ditemukan. Orang utan tidak dapat berenang.

\section{e. Perilaku Khas}

Orang utan dapat menggunakan tongkat sebagai alat bantu untuk mengambil makanan, dan menggunakan daun sebagai pelindung sinar matahari. Orang utan Sumatera usia 6 tahun yang hidup di rawabarat Sungai Alas Sumatera menggunakan tongkat untuk mendeteksi madu tapi perilaku tersebut tidak pernah ditemukan di antara orang utan di wilayah pesisir timur. Hal ini menunjukkan keragaman perilaku dalam adaptasi lingkungan. Orang utan jantan terbesar memiliki rentangan lengan (panjang dari satu ujung tangan keujung tangan yang lain apabila kedua tangan direntangkan) mencapai $2.3 \mathrm{~m}$. Orang utan jantan dapat membuat panggilan jarak jauh yang dapat didengar dalam radius $1 \mathrm{~km}$. Digunakan untuk menandai atau mengawasi arealnya, memanggil sang betina, mencegah orang utan jantan lainnya yang mengganggu. Mereka mempunyai kantung tenggorokan yang besar yang membuat mereka mampu melakukannya.

\section{Trenggiling}

Potensi trenggiling (Manis javanica Desmarest, 1822) di Indonesia cukup banyak diantaranya sebagai bahan obat untuk antiseptik, anti inflamasi, pengobatan skabies, rematik, jantung dan penyakit asma, serta sebagai bahan baku kosmetik (Akmal et al., 2014b; Akmal et al., 2019). Trenggiling (Manis javanica) merupakan binatang nokturnal yang aktif melakukan kegiatan hanya di malam hari. Umumnya ditemukan hidup soliter (sendiri), meskipun kadangkala ditemukan hidup berpasangan. Satwa langka ini mampu berjalan beberapa kilometer dan balik lagi kelubang sarangnya yang ditempatinya untuk beberapa bulan. Binatang ini mempunyai bentuk tubuh khas yang memanjang dan tertutupi sisik. Panjang dari kepala hingga pangkal ekor mencapai $58 \mathrm{~cm}$. Panjang ekor mencapai $45 \mathrm{~cm}$. Berat tubuh trenggiling sekitar 2 kg. Trenggiling (Manis javanica) mempunyai bentuk tubuh yang memanjang, dengan lidah yang dapat dijulurkan hingga sepertiga panjang tubuhnya untuk mencari semut di sarangnya. Tenggiling adalah hewan yang tergolong dalam golongan kelas Mamalia. Tenggiling adalah haiwan berdarah panas, melahirkan anak, menjaga anak, dan mempunyai bulu dan sisik di badan. Tubuh tenggiling lebih besar dari kucing. Kakinya pendek dan ekornya panjang. Tubuhnya bersisik. Sisik pada bagian punggung dan bagian luar kaki tenggiling berwarna coklat terang. Ia tidak mempunyai gigi. Ia memangsa makanan berupa semut dan serangga menggunakan lidahnya. Jantung Tenggiling terdiri daripada 4 bahagian seperti manusia. Bahagian atas dikenali sebagai atrium, sementara bagian bawah dikenali sebagai ventrikel.

Berikut adalah klasifikasi dari trenggiling :

$\begin{array}{ll}\text { Kingdom } & \text { : Animalia } \\ \text { Phyllum } & \text { : Chordata } \\ \text { Sub Phyllum } & \text { : Vertebrata } \\ \text { Classis } & \text { : Mammalia } \\ \text { Ordo } & \text { : Polidota } \\ \text { Familia } & \text { : Manidae } \\ \text { Genus } & : \text { Manis } \\ \text { Species } & : \text { Manis javanica }\end{array}$

Trenggiling (Manis javanica) habitatnya di daerah hutan hujan tropika amat sesuai sebagai habitat hidupan liar ini. Trenggiling kadang juga dikenal sebagai anteater. Tinggal di lubang-lubang bawah pokok, bagian akar pohon, dalam lubang dan sarang anai-anai dan semut yang digali, serta pada batang pokok yang berlubang. Trenggiling (Manis javanica) satwa ini tersebar di Nias, Mentawai, Sumatera, Riau. Pulau Lingga, Kalimantan, tentu saja di Jawa hingga Bali dan Lombok. Bisa dikatakan tersebar di Indonesia Barat. Bahkan sejenisnya pun bisa dijumpai di Burma, MalaysiaSingapura dan Filipina. Sedangkan saudara sejenisnya bisa dijumpai sampai di Afrika. Selain terdapat di pulau Jawa, Sumatera, Kalimantan (Indonesia) juga terdapat di negara Malaysia, Brunei Darussalam, Kamboja, Laos, Myanmar, Thailand, dan Vietnam. Beberapa jenis spesies trenggiling yang dapat ditemukan dibelahan dunia:

1. Manis javanica, hidup tersebar di Indonesia, Malaysia, dan Indochina.

2. Manis pentadactyla, hidup di Nepal, Himalaya timur, Myanmar, dan china

3. Manis carssicaudatam, hidup di india dan srilangka.

4. Manis tertadactyla, hidup di asia 
5. Manis temmenki hidup di asia

6. Manis triscuspis hidup di asia

7. Manis gigantean hidup di afrika

Trenggiling adalah mamalia unik bersisik satu-satunya dari famili Pholidota. Sisik pada Trenggiling yang berfungsi sebagai alat berlindung dari mangsa, sayangnya kinii menjadi ancaman karena menjadi targer perburuan liar dan membawanya kedalam status Genting atau Terancam (Endangered) yang dikeluarkan oleh IUCN, merupakan status konservasii yang diberikan kepada spesies yang sedang menghadapi resiko kepunahan di alam liar yang tinggi pada waktu yang akan datang

\section{a. Perilaku Makan}

Sebelum makan, Trenggiling mencium dan mendengus makanannya terlebih dahulu lalu menjulurkan lidahnya untuk mengambil makanan. Perilaku makan juga dipengaruhi oleh genetika, habitat, ketersediaan pakan, dsb. Pakannya berupa Kroto dan diampur dengan dedak. Kondisi biologis pun dapat mempengaruhi perilaku makan. Mereka yang sedang berpasangan memiliki interaksi sosial, usia mereka dan sehat atau tidak mempengaruhi perilaku makan mereka.

\section{b. Perilaku Seksual}

Reproduksi pada trenggiling terjadi setahun sekali selama musim kawin, baik pada musim gugur dan musim panas. Trenggiling memiliki sepasang organ reproduksi yang terdiri atas testes, epididymis dan ductus deferens yang selanjutnya bermuara ke urethra (Akmal et al., 2014a; Akmal et al., 2014b), sedangkan kelenjar aksesori kelamin jantan trenggiling pada trenggiling terdiri atas glandula vesicularis dan prostat serta bulbourethralis (Akmal et al., 2015; Akmal et al., 2019). Reproduksi pada trenggiling terjadi setahun sekali selama musim kawin, baik pada musim gugur dan musim panas.

Hewan ini adalah spesies yang sangat terisolasi dan teritorial, musim kawin adalah satusatunya waktu mereka untuk berinteraksi antara trenggiling. trenggiling jantan akan menarik trenggiling betina dengan cara buang air kecil, tindakan yang menghasilkan bau yang kuat dan betinanya kemudian dapat mengidentifikasi dan menemukan menggunakan penciuman mereka yang luar biasa. Meskipun tidak sering terjadi dalam alam liar, dua trenggiling jantan dalam sebuah wilayah yang sama mungkin memperebutkan betina, menggunakan ekor mereka untuk mengetuk jantan lain. Setelah kopulasi pada hewan ini terjadi dan trenggiling betina akan hamil selama 120-150 hari. Selama waktu ini, trenggiling betina tidak mengalami perubahan besar, kecuali pembengkakan perutnya. Ketika trenggiling lahir, mereka memiliki berat sekitar 80 sampai dengan $450 \mathrm{~g}$ dan panjang sekitar 6 inci. Demikian juga, sisik mereka masih lembut, putih, dan tidak tumpang tindih atau akan mengeras sampai dua hari kemudian. Trenggiling muda akan dapat berjalan setelah berumur dua minggu. Meskipun demikian, mereka melakukan perjalanan mengikuti ekor ibu mereka. ibu hewan ini menyusui anak-anak mereka dari kelenjar susu sampai mereka berusia tiga sampai empat bulan. Begitu mereka telah mencapai usia ini, mereka mulai makan semut, rayap dan semua serangga lain yang ditemukannya. Pada usia dua tahun, ketika trenggiling telah mencapai kematangan seksual, yang trenggiling ibu akan akhirnya meninggalkan anak-anak mereka.

\section{c. Perilaku Sosial}

Trenggiling merupakan binatang soliter, tidak berkelompok. Siang hari dia tidur di dalam liang yang digali olehnya, baru pada malam hari dirinya keluar aktif mencari makan, dan untuk keperluannya itu, Trenggiling mengandalkan penciumannya yang tajam.

\section{d. Perilaku Pergerakan}

Perilaku bergerak berupa aktivitas berjalan, mendatangi pakan, memanjat dan berdiri. Perilaku berjalan berupa berpindah tempat menggunakan keempat tungkainya dan dilakukan setelah ia bangung tidur untuk memeriksa lingkungan sekitarnya. Aktivitas berjalan menuju tempat pakan dipengaruhi oleh suhu sekitar kandang untuk beradaptasi dengan lingkungan. Aktivitas memanjat berupa gerakan vertikal dari lantai lalu naik ke atas pohon atau pagar besi kandang. Kaki depan digunakan untuk mengangkat tubuhnya ke atas dan kaki belakangnya berfungsi mendorong tubuhnya. Tidak semua Trenggiling berada di tanah, ada jenis Trenggiling yang suka memanjat pohon dan bergelantungan di sana. Jenis Trenggiling Afrika yang secara total berada di daratan adalah jenis Smutsia temminckii dan Smutsia gigantea, 
sedangkan yang bisa memanjat pohon dan bergelantungan di sana adalah Manis tricuspis dan Manis tetradactyla. Ciri khusus Trenggiling yang bisa memanjat dan bergelantungan di pohon adalah ukuran tubuhnya yang relatif lebih kecil dan memiliki ekor yang cukup panjang.

Trenggiling merupakan hewan nokturnal dan mereka lebih suka tidur pada siang hari. Ketika cuaca panas, satwa ini akan bangun dan membasahi tubuhnya. Adapun posisi tidur yang umum dilakukan Trenggiling adalah melingkar, terlentang dan memanjang. Posisi melingkar yaitu kepala dan kakinya menyentuh perut melingkar seperti bola. Posisi ini dilakukan untuk menghindari gangguan dari luar. Posisi terlentang yaitu kaki depan memegang kawat atau pohon yang ada di kandang. Sedangkan posisi memanjang dilakukan jika satwa tersebut tidur di bak air karena kepanasan.

Pada Trenggiling jantan, memanjat memiliki fungsi menguatkan otot kakinya pada saat menaiki trenggiling betina. Sedangkan pada Trenggiling betina berfungsi untuk menghindari pejantan yang masih ingin kawin padahal betina sedang bunting. Aktivitas berdiri sering dilakukan oleh Trenggiling jantan ketika merasakan adanya bahaya atau gangguan. Aktivitas berdiri dilakukan dengan menggunakan dua kaki belakang dan menegakan tubuhnya untuk mendengus dan membaui daerah sekitarnya. Aktivitas mendatangi pakan dan minum bersamaan dengan membersihkan tubuhnya dengan mandi di bak air.

\section{e. Perilaku khas}

Trenggiling akan membentuk tubuhnya menjadi seperti bola saat dirinya merasa ada ancaman mendekat. Saat seperti itu, Trengiling akan mengeluarkan bau-bauan yang tidak sedap layaknya seekor sigung. Bahkan, seekor singa ataupun harimau tidak mampu membuka bola Trenggiling untuk memangsanya. Sisik-sisik yang menempel di tubuh Trenggiling terus tumbuh sepanjang hidup mereka, layaknya rambut manusia.Trenggiling mempunyai penglihatan yang payah. Oleh karena itu, dalam mencari sarang semut dan rayap, Trenggiling menggunakan indera penciuman mereka.

\section{Gajah sumatera}

Gajah Sumatera (Elephas maximus sumatranus) merupakan salah satu anggota dari ordo proboscidea yang terancam kelestariannya. Gajah dapat dikelompokan ke dalam dua kelompok yaitu gajah Asia dan gajah Afrika. Gajah sumatera (Elephas maximus sumatranus) merupakan sub spesies gajah Asia yang umumnya hidup di daerah dataran rendah, dan tinggi di kawasan hutan hujan tropika pulau Sumatera. Satwa ini merupakan spesies yang hidup dengan pola matriarchal yaitu hidup berkelompok dan dipimpin oleh betina dewasa dengan ikatan social yang kuat.

Dalam memilih habitatnya, Gajah Sumatera memperhitungkan berbagai kondisi faktor habitat misalnya ketersediaan tempat mencari makan, penutupan tajuk sebagai tempat berlindung dan tersediannya sumber air. Habitat gajah meliputi seluruh hutan di pulau Sumatera dari Lampung sampai Provinsi Aceh, mulai dari Hutan Basah Berlembah dan Hutan Payau di dekat pantai sampai Hutan Pegunungan pada ketinggian $2000 \mathrm{~m}$. Kelangsungan hidup Gajah Sumatera makin terancam karena tingginya tekanan dan gangguan serta kurangnya pengetahuan tentang bagaimana cara hidup gajah di habitat aslinya yang dibutuhkan sebagai acuan pengelolaan populasi alami. Pada dasarnya gajah sangat selektif dalam memilih habitatnya, karena gajah merupakan salah satu hewan yang memiliki kepekaan. Pengetahuan ekologis tentang bagaimana strategi gajah menggunakan habitat dan sumber daya masih sangat terbatas.

Gajah sumatera masuk kedalam kategori Internasional Union Conservation of Nature (IUCN) dengan status spesies Kritis (Critically Endangered) adalah status konservasi yang diberikan kepada spesises yang menghadapi risiko kepunahan diwaktu dekat

\section{a. Perilaku Makan}

Gajah sumatera memakan rumputrumputan, daun, ranting, umbiumbian dan kadang buah-buahan. Setidaknya terdapat 69 spesies tumbuhan yang bisa dijadikan pakan gajah. Tumbuhan tersebut terdiri dari 29 kelompok rumputrumputan dan 40 kelompok tanaman non rumput. Gajah sumatera diketahui lebih menyukai rumputrumputan. Efesiensi sistem pencernaan gajah sangat buruk. Hewan ini bisa membuang fesesnya setiap 
satu jam sekali. Tidaklah heran bila dalam sehari gajah sumatera memerlukan makanan hingga $230 \mathrm{~kg}$ atau setara dengan 5-10\% dari bobot tubuhnya. Sedangkan untuk minum dibutuhkan 160 liter air setiap hari. Di musim kemarau gajah sumatera bisa menggali air di dasar sungai yang mengering hingga kedalaman satu meter.

\section{b. Perilaku Seksual}

Gajah jantan memiliki periode musth, yaitu masa produksi hormon testosteon. Musth menandakan bahwa gajah jantan sudah siap kawin. Secara umum gajah jantan akan mengalami musth setelah berumur sekitar 12-15 tahun. Saat gajah jantan memasuki periode musth akan terjadi perubahan perilaku, nafsu makannya menurun, gerakannya lebih agresif dan suka mengendusngendus dengan belalainya. Selain itu terjadi juga perubahan fisik seperti sering meneteskan urin, penis sering keluar dan dari dahinya mengeluarkan kelenjar berbau menyengat. Gajah betina bisa melahirkan anak setelah berumur di atas 910 tahun. Usia kehamilan mencapai 22 bulan. Bayi gajah sumatera yang baru lahir memiliki bobot tubuh sekitar 40-80 kg dengan tinggi 75-100 cm. Bayi tersebut akan diasuh oleh induknya hingga berumur 18 bulan. Dalam satu kali kehamilan biasanya terdapat satu bayi, namun dalam beberapa kasus ada juga yang melahirkan hingga dua bayi. Jarak waktu antar kehamilan berkisar 4-4,5 tahun. Gajah tidak mempunyai musim kawin yang tetap dan bisa melakukan kawin sepanjang tahun, namun biasanya frekwensinya mencapai puncak bersamaan dengan masa puncak musim hujan di daerah tersebut. Gajah jantan sering berperilaku mengamuk atau kegilaan yang sering disebut musht dengan tanda adanya sekresi kelenjar temporal yang meleleh di pipi, antara mata dan telinga, dengan warna hitam dan berbau merangsang. Perilaku ini terjadi 3-5 bulan sekali selama 1-4 minggu. Perilaku ini sering dihubungkan dengan musim birahi, walaupun belum ada bukti penunjang yang kuat.

\section{c. Perilaku Sosial}

Gajah merupakan hewan sosial yang hidup berkelompok. Kelompok berperan penting dalam menjaga kelangsungan hidup gajah. Jumlah anggota kelompok sangat bervariasi. Tergantung pada kondisi sumber daya alam dan luas habitat. Gajah sumatera bisa ditemukan dalam kelompok yang terdiri dari 20-35 ekor, tetapi juga ada kawanan yang hanya 3 ekor saja. Setiap kelompok dipimpin oleh seekor betina. Sedangkan yang jantan berada dalam kelompok untuk periode tertentu saja. Gajah yang tua akan hidup memisahkan diri dari kelompoknya hingga pada akhirnya mati. Gajah sumatera sangat peka dengan bunyi-bunyian. Untuk melakukan perkawinan dan berkembang biak, gajah memerlukan suasana yang tenang dan nyaman. Suara alat-alat berat dan gergaji mesin sangat menganggu perkembangbiakan gajah. Di habitat alamnya, gajah hidup berkelompok (gregarius). Perilaku berkelompok ini merupakan perilaku sosial yang sangat penting peranannya dalam melindungi anggota kelompoknya. Besarnya anggota setiap kelompok sangat bervariasi tergantung pada musim dan kondisi sumber daya habitatnya terutama makanan dan luas wilayah jelajah yang tersedia. Setiap kelompok gajah sumatera dipimpin oleh induk betina yang paling besar, sementara yang jantan dewasa hanya tinggal pada periode tertentu untuk kawin dengan beberapa betina pada kelompok tersebut. Gajah yang sudah tua akan hidup menyendiri karena tidak mampu lagi mengikuti kelompoknya. Gajah jantan muda dan sudah beranjak dewasa dipaksa meninggalkan kelompoknya atau pergi dengan suka rela untuk bergabung dengan kelompok jantan lain. Sementara itu, gajah betina muda tetap menjadi anggota kelompok dan bertindak sebagai bibi pengasuh pada kelompok "taman kanak-kanak" atau kindergartens.

\section{d. Perilaku Pergerakan}

Kelompok gajah bergerak dari satu wilayah ke wilayah yang lain, dan memiliki daerah jelajah (home range) yang terdeterminasi mengikuti ketersediaan makanan tempat berlindung dan berkembang biak. Luasan daerah jelajah akan sangat bervariasi tergantung dari ketiga factor tersebut. Belum pernah ada penelitian yang komprehensif tentang luasan daerah jelajah untuk gajah sumatera dan kalimantan, namun pada sub spesies gajah asia lainnya seperti di India diketahui bahwa daerah jelajah gajah asia sangat bervariasi. Luas home range dengan metode Kernel dapat menggambarkan intensif penggunaan habitat gajah. Sehingga dapat diketahui area mana yang menjadi inti dalam pergerakan dan aktivitasnya. Metode kernel menggambarkan efisiensi penggunaan habitat 
dibandingkan MCP, yang dapat dipakai untuk menajemen habitat dengan tujuan tertentu.

\section{e. Perilaku Khas}

Perilaku Menggaram Gajah Sumatera

(Elephas maximus sumatranus) Gajah sering mengunjungi saltlicks (tempat menggaram) untuk mencari garam mineral. Menggaram dilakukan secara alami untuk mencari nutrisi yang sangat penting untuk kelangsungan hidupnya. Gajah mampu melakukan perjalanan jarak jauh untuk mengunjungi tempat menggaram, dan mengkonsumsi garam mineral dalam jumlah banyak sebagai pencahar. Gajah melakukan aktivitas menggaram saat merasa tubuhnya tidak sehat. kondisi kesehatan gajah sumatera berpengaruh terhadap frekuensi menggaram. Gajah jantan menggaram dengan cara mengendus sumber garam lalu mengambil sedikit tanah atau lumpur dengan belalai, kemudian dimasukkan kedalam mulut. Gajah menggunakan lumpur untuk melindungi kulitnya dari sinar ultraviolet, walaupun kulit gajah sebenarnya sangat sensitif. Bila gajah tidak secara rutin berkubang dalam lumpur, kulitnya akan mengalami kerusakan akibat sinar matahari, gigitan serangga, dan hilangnya kelembaban. Setelah berkubang, gajah biasanya menggunakan belalainya untuk menyemburkan debu ke tubuhnya, dan debu ini akan mengering menjadi kerak pelindung. Gajah mengalami kesulitan dalam mengeluarkan panas dari kulitnya karena rasio luas permukaan terhadap volumenya yang jauh lebih rendah dari manusia. Sementara itu, beberapa gajah didapati mengangkat kaki mereka untuk memaparkan tapak kakinya ke udara. Pada waktu berendam di sungai, gajah minum dengan mulutnya. Sementara, pada waktu di sungai yang dangkal atau di rawa gajah menghisap dengan belalainya. Gajah mampu menghisap mencapai 9 liter air dalam satu kali isap. Gajah sering berkubang di lumpur pada waktu siang atau sore hari di saat sambil mencari minum. Perilaku berkubang juga penting untuk melindungi kulit gajah dari gigitan serangga ektoparasit, selain untuk mendinginkan tubuhnya. Gajah mencari garam dengan menjilatjilat benda dan apapun yang mengandung garam dengan belalainya. Gajah juga sering melukai bagian tubuhnya agar dapat menyikat darahnya yang mengandung garam. Gajah tidur dua kali sehari, yaitu pada tengah malam dan siang hari. Pada malam hari, gajah sering tidur dengan merebahkan diri kesamping tubuhnya, memakai "bantal" terbuat dari tumpukan rumput dan kalau sudah sangat lelah terdengar pula bunyi dengkur yang keras. Sementara itu, pada siang hari gajah tidur sambil berdiri di bawah pohon yang rindang. Perbedaan perilaku ini, mungkin berkaitan dengan kondisi keamanan lingkungan. Apabila kondisinya kurang aman maka gajah akan memilih tidur sambil berdiri, untuk menyiapkan diri jika terjadi gangguan

\section{Beruk}

Beruk (Macaca namestrina) merupakan Primata yang mempunyai panjang ekor $1 / 3$ dari panjang badannya ini termasuk ke dalam kelompok binatang yang aktif di siang hari atau disebut dengan satwa "diurnal". Primata ini memiliki beberapa nama daerah seperti: beruk atau bangkuy dan kera ekor babi. Satwa ini biasanya hidup berkelompok hingga mencapai 15 -40 ekor per kelompok. Makanan primata ini meliputi buah-buahan yang masak juga hewan vertebrata dan invertabrata kecil.Beruk mempunyai ciri-ciri yang berbeda dengan Macaca pada umumnya. Tubuh Beruk berukuran panjang $47.0-58.5 \mathrm{~cm}$, dengan panjang ekor $14-23 \mathrm{~cm}$ dan berat tubuh kisaran $3.5-9 \mathrm{~kg}$. Tubuhnya tertutup oleh mantel rambut berwarna coklat keabu-abuan dan kemerah-merahan. Di bagian kepala, leher, punggung sampai ekor berwarna gelap dan dibagian lain berwarna terang, muka dari samping nampak moncong ke depan sedang jika dilihat dari depan nampak bulat, di bagian atas nampak rambut membentuk setengah lingkaran berwarna coklat kemerahan. Penyebaran beruk yaitu di daerah tropis, seperti Indonesia (hutan Sumatra, Sulawesi, dan Kalimantan), Malaysia, dan Thailand dengan wilayah tinggal adalah kawasan hutan hujan, pesisir, atau ladang perkebunan.

Berikut adalah klasifikasi dari beruk :

$\begin{array}{ll}\text { Kerajaan } & \text { : Animalia } \\ \text { Phylum } & \text { : Chordata } \\ \text { Classis } & \text { : Mamalia } \\ \text { Ordo } & \text { : Primata } \\ \text { Family } & \text { : Cercopithecidae } \\ \text { Genus } & \text { : Macaca } \\ \text { Species } & \text { : Macaca nemestrina }\end{array}$

Hewan beruk termasuk hewan yang saat ini dicoba untuk dilestarikan, mengingat statusya dalam 
IUCN termasuk kategori Kritis (Critically Endangered), yang artinya akan segera punah jika tidak segera dilestarikan. Oleh karena itu, sekarang ini di beberapa wilayah seperti di Indonesia ada lokasi penangkaran khusus untuk hewan ini.

\section{a. Perilaku Makan}

Beruk dalam mencari makanannya cenderung memilih pohon pakan yang memiliki percabangan banyak. makanan sangat bervariasi mulai dari buah-buahan biji-bijian daunan dan serangga Selain itu beruk juga makan nasi yang diperoleh dari tempat sampah yang ada di sekitar kawasan konservasi atau pemukiman. Beruk adalah binatang omnivora. Makanan utama beruk adalah buahbuahan, biji-bijian, jamur, dan tak jarang pula hewan ini akan memakan hewan invertebrata seperti cacing, kelabang, atau lainnya. Dalam mengambil makanannya baik pucuk daun maupun buah beruk menggunakan kedua tangannya, jika buah yang dimakan berukuran besar berupa kadang-kadang menggunakan kedua tangan dan kakinya, sehingga buat tersebut bisa dimakannya. untuk aktivitas minum beruk biasanya minum dari air sungai dan air genangan maupun air yang berasal dari lubanglubang pohon. Hewan yang satu ini termasuk hewan diurnal, dimana semua aktivitas mengumpulkan makanan akan dilakukan saat siang hari dan pada saat malam hari, hewan ini akan tinggal berkelompok untuk menghindari serangan predator.

\section{b. Perilaku Seksual}

Beruk memiliki masa reproduksi aktif setelah berusia 3-5 tahun. Beruk betina akan hamil dalam siklus selama 6 bulanan. beruk akan melahirkan satu anak setiap periode 2 tahun sekali. Anak beruk akan disapih setelah berusia 4 hingga 5 bulan. Fase reproduksi individu betina umumnya berulang setiap dua tahun sekali dengan musim yang berlangsung antara Januari hingga Mei. Habitat beruk adalah hutan hujan dengan ketinggian sekitar 2000 mdpl. Namun kadang mereka juga terlihat di ladang dan perkebunan penduduk. Pada saat reproduksi, hewan yang satu ini memiliki karakter khas, dimana hewan jantan akan memperlihatkan giginya dan melakukan gerakan khusus untuk menarik individu betina. Jika dikembangbiakkan dalam penangkaran, hewan yang satu ini memiliki masa hidup yang bisa mencapai 26 tahun. Hal tersebut karena tingkat persaingan di area penangkaran umumnya lebih kecil daripada alam liar. Pada saat menyapih anak beruk, individu betina bisa berjalan cepat atau bergelantungan dengan menggendong anakan di area perutnya. Hal tersebut juga bertujuan untuk melindungi anakan dari pemangsa.

\section{c. Perilaku Sosial}

1.) Perilaku interaksi sosial antar individu Interaksi sosial antar individu dilakukan melalui aktivitas grooming, bermain dan kawin. Aktivitas grooming biasanya dilakukan pada saat istirahat. Aktivitas bermain banyak dilakukan pada individu anak. Sedangkan aktivitas kawin dilakukan oleh individu jantan dan betina dewasa. Tidak jarang aktivitas ini dilakukan dengan dua individu tersebut secara bergantian. Aktivitas kawin dilakukan dalam waktu yang sangat singkat yaitu minimal tiga detik. Dalam sehari individu jantan dewasa dapat mengawini lebih dari 2 ekor individu betina dewasa maupun muda yang produktif. Individu jantan dewasa selalu berdekatan dengan individu betina yang sedang estrus dibandingkan dengan individu yang lain individu betina yang sedang estrus bersifat lebih agresif. aktivitas kawin biasanya dilakukan hanya pada saat setelah bangun tidur dan setelah makan.

2.) Perilaku interaksi sosial dengan spesies yang lain

Beruk memiliki sifat yang lebih agresif dibandingkan dengan Primata yang lain dalam menghadapi gangguan. Misalnya melihat pengamat atau satuan lain biasanya melakukan gerakan badan dan mimik wajahnya dengan menganjurkan mulutnya seperti mengejek dan alis mata secara bersamaan ditarik ke atas. Memperlihatkan pelupuk matanya. Komunikasi dilakukan dengan mata dan suara-suara yang dikeluarkan berupa suara dengkuran yang kasar dan geraman. Hewan yang satu ini hidup secara berkelompok, dimana antara individu jantan dan betina terdapat suatu sistem kasta yang tidak terlihat jelas. Kasta tersebut akan menentukan individu jantan maupun betina yang menjadi pemimpin. Beruk jantan akan terbagi-bagi kedudukannya berdasarkan kekuatannya, sedangkan beruk betina berdasarkan keturunannya. Anak betina dari beruk betina yang dominan akan memiliki kedudukan yang di atas semua betina lainnya dalam satu kelompok. Beruk betina yang dominan akan 
memimpin grup tersebut, ataupun individu betina yang menjadi pemimpin adalah individu yang memiliki banyak keturunan. sedangkan pejantan lebih berfungsi sebagai peredam jika terjadi konflik dalam kelompok tersebut. Dalam kawanan beruk, pemimpin jantan umumnya memiliki suara paling nyaring dan suara tersebut akan makin terdengar ketika ada konflik dalam kawanan atau ada predator yang sedang mendekat. Komunikasi suara yang khas dalam kawanan juga digunakan saat pemimpin sedang memimpin kawanannya untuk melakukan migrasi. Tinggi rendah suara yang ada, diterjemahkan sebagai arah migrasi dan koordinasi kawanan. Beruk termasuk hewan yang cukup pintar dan bisa dilatih untuk keperluan manusia, salah satu contohnya ketika manusia melatihnya untuk menerima makanan dengan tangan kanan, lama kelamaan beruk juga akan mengikutinya selain itu beruk juga biasa dimanfaatkan sebagai hewan untuk memanen buah buahan, seperti kelapa, mangga dan buah lainya. Istirahat merupakan aktivitas yang meliputi posisi tidur yang mengawasi sekitar dan grooming atau menelisik. Aktivitas ini biasanya dilakukan setelah mencari makan atau setelah melakukan pergerakan untuk mencari makan. Namun aktivitas ini sering dilakukan pada siang hari karena pada siang hari cuaca panas, sehingga beruk lebih sering berada pada tempat-tempat yang teduh. biasanya beruk lebih senang beristirahat pada pohon-pohon yang tinggi dan lebat seperti pohon kempas jambu jambu dan ara. Pada saat istirahat beruk lebih senang berkutu-kutuan. Aktivitas grooming biasanya dilakukan secara berpasangpasangan atau secara individual-individual. Beruk yang sering melakukan aktivitas grooming adalah individu betina dewasa yang berpasangan dengan anaknya. atau dengan individu muda dengan jantan dewasa.

\section{d. Perilaku Pergerakan}

Beruk hidup diatas pohon, perpindahan untuk mendapatkan makanan biasanya dilakukan diatas tanah. Satwa ini hidup berkelompok terdiri dari 5-6 ekor sampai 40 ekor. Kelompok ini tidak menetap di suatu areal tertentu, namun selalu berpindahpindah. Di dalam kelompok sering dibagi menjadi kelompokkelompok yang lebih kecil. Jika dalam keadaan bahaya akan menunjukkan perlawanan (Attack) dengan ekspresi gerakan mereka yang lebih agresif. Perilaku berpindah atau Movement dalam pergerakan yang berorientasi pada lokasi makan dan tempat istirahat kemudian kembali menuju lokasi makan serta lokasi tidur pada sore hari, seperti halnya dengan primata yang lain lebih banyak bergerak dalam rangka untuk mencari makan mencari air dan untuk berkembangbiak ataupun untuk menghindari diri dari pemangsa dan gangguan yang lain. Beruk melakukan aktivitas perpindahan dilakukan dengan melompat dari satu pohon ke pohon lain ataupun dengan berjalan di atas permukaan tanah. Berdasarkan pengamatan beruk ini selalu melakukan pergerakan di atas pohon dengan ketinggian antara 1 sampai 20 meter daripada bergerak di atas tanah. posisi beruk dalam penggunaan pohon sangat bervariasi tergantung status sosial buruk dalam kelompoknya.

\section{e. Perilaku Khas}

Beruk termasuk hewan homoioterm yang memiliki suhu tubuh tetap, dengan demikian hewan ini mampu bertahan hidup untuk cuaca yang cukup ekstrim tanpa perlu tinggal didalam lubang. Menjelang malam hari bersiap-siap untuk melakukan aktivitas tidur. Dalam mencari pohon tidur beruk melakukan seleksi pohon yang digunakan sebagai tempat tidur. Pada umumnya merupakan pohon sumber makan yang terletak dekat dengan pohon makan terakhir. Pada sore hari hal ini dimungkinkan pada pagi berikutnya kelompok beruk ini akan mengunjungi pohon pakan yang sama dekat posisi tidur beruk. Saat istirahat beruk dengan duduk atau rebahan berbaring posisi tersebut dilakukan untuk menghindari adanya gangguan dari pemangsa atau satwa yang lain. Kelompok beruk ini tidur secara terpisah - pisah berdasarkan kelompoknya. Pohon yang sering digunakan untuk tidur antara lain Kempas, jambu-jambuan dan Ara.

Beruk (Macaca nemestrina) termasuk binatang terestrial (banyak menghabiskan waktunya di darat), tetapi mereka juga sangat terampil dalam memanjat. Beruk juga berbeda dengan primata kebanyakan, jika kebanyakan primata jaga jarak dengan air, beruk justru senang bermain air. Beruk hidup dalam sebuah kelompok besar yang terbagi menjadi beberapa kelompok yang lebih kecil selama mencari makan di siang hari. 


\section{Tapir}

Tapir Asia(Tapirus indicus) atau di Indonesia biasa disebut Tapir, merupakan Satu dari empat spesies tapir yang ada di dunia. Dibandingkan dengan spesies Tapir lainnya Tapir Asia memiliki ukuran tubuh yang paling besar. Satwa yang oleh IUCN digolongkan berstatus endangered (EN Genting/Terancam) dan merupakan satwa yang dilindungi di Indonesia berdasarkan PP Nomor 7 Tahun 1999 ini dapat ditemukan di Indonesia (Sumatera), Malaysia, Myanmar dan Thailand.

Tapir sering beraktivitas pada malam hari berkaitan dengan karakteristik tubuhnya. Mengenai karakteristik fisik, tapir memiliki pendengaran dan penciuman yang ber-kembang dengan baik, namun tidak untuk penglihatan. Tapir asia memiliki tubuh gempal besar dengan hidung menonjol menyerupai belalai. Tapir dewasa memliki pola warna dramatis, dengan setengah tubuh depan berwarna putih, dan seluruh kaki depan dan belakang berwarna hitam. Mata berbentuk oval dan tidak sangat serasi dengan tubuhnya. Kaki depan memiliki empat kuku, tetapi hanya ujung kuku keempat (belakang) tidak menyentuh tanah, sehingga jejak kaki menunjukkan jejak tiga kuku. Sedangkan kaki bagian belakang hanya memiliki tiga kuku.

\section{a. Perilaku Makan}

Tapir merupakan hewan pemakan tumbuhan tetapi bukan termasuk ke dalam hewan ruminansia. Pakan tapir terdiri dari berbagai macam rumput, daun tumbuhan air dan ranting. Tapir sering menggunakan hidungnya untuk menarik ranting dan daun untuk dimasukkan ke dalam mulut. Hewan ini mencari makan pada rute yang sama.

\section{b. Perilaku Seksual}

Masa kawin terjadi pada bulan april dan mei. Masa kehamilan terjadi selama 390 hari. Anakan tapir yang lahir memiliki berat berkisar 910 $\mathrm{kg}$. Tapir muda dari semua jenis berbulu cokelat dengan garisgaris dan bintik-bintik putih. Pola pada bayi ini berubah menjadi pola warna tapir dewasa antara empat hingga tujuh bulan setelah kelahiran.anak tapir disapih antara 6 dan 8 bulan dan binatang ini menjadi dewasa pada umur tiga tahun. Kematangan seksual terjadi setelah tapir berumur 3 tahun.

\section{c. Perilaku Sosial}

Tapir Asia terutama merupakan hewan penyendiri, menandai jalurjalur besar di darat sebagai teritori atau daerah kekuasaannya, meski daerah ini biasanya bertumpang tindih dengan daerah kekuasaan individu lain. Tapir menandai teritorinya dengan mengencingi tetumbuhan dan mereka sering mengikuti jalur lain dari yang telah mereka buat yang telah ditumbuhi tumbuhan.

\section{d. Perilaku Pergerakan}

Berdasarkan pola aktivitasnya, tapir digolongkan menjadi primata yang nokturnal (aktif pada malam hari) walaupun mereka tidak benarbenar nocturnal. Mereka cenderung mencari makan saat matahari terbenam dan juga sering tidur disiang hari. Tingkahla ku ini menandai bahwa mereka dapat dikatakan sebagai satwa krepuskular.

\section{e. Perilaku Khas}

Tapir Asia merupakan hewan penyendiri, menandai jalur-jalur besar di darat sebagai teritori atau daerah kekuasaannya, meski daerah ini biasanya bertumpang tindih dengan daerah kekuasaan individu lain. Tapir menandai teritorinya dengan mengencingi tetumbuhan dan mereka sering mengikuti jalur lain dari yang telah mereka buat yang telah ditumbuhi tumbuhan.

\section{KESIMPULAN}

Kesimpulan yang didapatkan pada pengamatan jurnal mengenai Lima perilaku satwa liar golongan mamalia, Tiga diantaranya seperti orangutan sumatera (Pongo Abelii), Gajah sumatera(Elephas maximus sumatranus) dan Beruk (Macaca namestrina) termasuk kedalam kategori status spesies Kritis (Criticaly endangered) sedangkan trenggiling (manis javanica), dan Tapir Asia (Tapirus indicus) termasuk kedalam kategori status spesies Genting (endangered) yang telah dikeluarkan oleh IUCN. Untuk itu perlu dilakukan upaya-upaya pelestarian atau kegiatan Reintroduksi yang bertujuan agar suatu jenis dapat berkembang biak kembali di habitatnya semula. Usaha ini diarahkan pada jenis hewan atau tumbuhan yan terancam punah. Dengan mengetahui terlebih dahulu perilaku keseharian masing-masing spesies tersebut. Keberadaan satwa endemik seperti gajah sumatera dan orangutan sumatera sangat penting, karena jika 
satwa tersbut punah di Indonesia maka itu artinya mereka punah juga di dunia.

\section{DAFTAR PUSTAKA}

Abdullah. Japisa, T. 2013. Karakterik Habitat Gajah Sumatera (Elephas maximus sumatranus temminck) Pada Habitat Terganggu Di Ekosistem Hutan Seulawah. Jurnal EduBio Tropika. Volume 1, Nomor 1.

Akmal, Y., Nisa, C., \& Novelina, S. (2014a). Anatomi Organ Reproduksi Jantan Trenggiling (Manis javanica). Acta Veterinaria Indonesiana, 2(2), 74-81.

Akmal, Y., Nisa, C., \& Novelina, S. (2014b). Anatomy of the Male Reproductive Organs of Javan Pangolin (Manis javanica). In Proceeding the 3 Joint International Meeting Bogor Indonesia P-03: 1 (Vol. 2). Hal: 69-70.

Akmal, Y., Muliari, Nisa, C., \& Novelina, S. (2015). Anatomy Accessory Glands Of Male Reproductive Of Javan Pangolin (Manis javanica). In Proceeding the 1th Almuslim International Conference on Science, Technology and Society (AICSTS), 1(1) Hal: 192-197.

Akmal, Y., Nisa, C., \& Novelina, S. (2019). Morfologi Kelenjar Aksesori Kelamin Jantan pada Trenggiling (Manis javanica) (Morphology Of The Male Sex Accessory Glands Of The Pangolin (Manis javanica)). Jurnal Veteriner, 20(36), 38-47. https://doi.org/10.19087/jveteriner.2019.20. 1.38

Alikodra, H.S. 1990. Pengelolaan Satwaliar. Bogor. Departemen Pendidikan dan Kebudayaan
Direktorat Jendral Pendidikan Tinggi. Pusat Anatar Universitas Ilmu Hayat Institute Pertanian Bogor

Fachrul, M., F. 2007. Metode Sampling Bioekologi. Bumi Aksara. Jakarta.

Marlius, E. Novarino, W, Risaldi. Dan Ardiyanto, A. 2018. Pola Aktivitas Tapir (Tapirus indicus Desmarest 1819) Di Hutan Kalaweit Supayang, Kabupaten Solok, Provinsi Sumatera Barat. Jurnal Metamoforsa. Volume (1): 16-21

Sawititri, R. Bismark, dan M. Takandjanjdi, M. 2012. Perilaku Trenggiling (Manis javanica Desmarest, 1822) Di Penangkaran Purwodadi, Deli Serdang, Sumatera Utara. Jurnal penelitian hutan dan konservasi alam. Vol. 9 No. 3 : 285-297.

Sofyan, H. Pudyatmoko, S. dan Imron. M., A. 2013 PERILAKU DAN JELAJAH HARIAN ORANGUTAN SUMATERA (Pongo abelli Lesson, 1827) REHABILITAN DI KAWASAN CAGAR ALAM HUTAN PINUS JANTHO, ACEH BESAR. Jurnal Ilmu Kehutanan. Volume VII No. 1

Winarno, G., D. dan Harianto, S., P. 2013. Perilaku Satwa Liar (Ethology). CV. Anugrah Utama Raharja (AURA). Bandar Lampung. 